\title{
GEOTOURISM DEVELOPMENT FOR FOSSIL CONSERVATION: A STUDY IN AMKHOI FOSSIL PARK OF WEST BENGAL IN INDIA
}

\author{
Premangshu CHAKRABARTY* \\ Visva-Bharati University, Faculty of Geography, Department of Geography, \\ Santiniketan, Bolpur, West Bengal, India, e-mail: drpremangshuindia@gmail.com \\ Rahul MANDAL \\ Visva-Bharati University, Department of Geography, \\ Santiniketan, Bolpur, West Bengal, India, e-mail: rahulskbu1992@gmail.com
}

\begin{abstract}
Citation: Chakrabarty, P. \& Mandal, R. (2019). GEOTOURISM DEVELOPMENT FOR FOSSIL CONSERVATION: A STUDY IN AMKHOI FOSSIL PARK OF WEST BENGAL IN INDIA. GeoJournal of Tourism and Geosites, 27(4), 1418-1428. https://doi.org/10.30892/gtg.27425-444
\end{abstract}

\begin{abstract}
Promotion of geotourism is recognized worldwide as a strategy for geoconservation. Fossil parks worldwide are one of the major geotourism attractions where in-situ conservation of fossil is encouraged. The angiosperm wood fossils have been discovered from Amkhoi, a tribal village of India in the year 2006. In order to prevent vandalism by the fossil hunters and antique thieves, a fossil park was planned that has been opened for the visitors from the beginning of 2018. This paper is an attempt to address the research gap on sustainable management of fossil parks while satisfying the geotourists with various facilities and amenities.
\end{abstract}

Key words: Geoconservation, geotourists, angiosperm, vandalism, sustainable

$$
* \quad * \quad * \quad * \quad *
$$

\section{INTRODUCTION}

Fossils are paleontological treasures manifesting remains of organism that existed in past geological ages. The study on fossils provides important keys for learning about the diversity and evolution of life through time (Boonchai et al., 2009). Fossil are of different types e.g. invertebrate fossil, vertebrate fossil, wood fossil and stromatolite fossil. Stromatolites, the oldest among fossils are the unique occurrence of bia-strome structures produced by blue-green algae in association with carbonate rocks in shallow water (Mishra, 2008). They have provided earliest records of life on earth dating back to 3.5 billion years ago. Marine Gondwana fossil park exhibits a rich collection of marine invertebrate category of fossil from the fossiliferous bed of Satpura Range on the right bank of Hasdeo River at Manendragarh in Chattisgarh of India. On the other hand, numerous well preserved vertebrate fossil assemblages have been discovered

\footnotetext{
* Corresponding author
} 
from Siwalik hill region in the north and Quaternary fluvial deposits in the Peninsular region (Badam, 1979, 1988; Badam \& Sathe, 1995). These vertebrate fossils belonged to Middle-Miocene or Early Middle Pleistocene in age. The paleoenviornmental histories and visualization of past ecological pyramids are among the motivations to draw the geotourists in fossil parks (Chakrabarty \& Mandal, 2019). Wood fossils, usually found in sedimentary rocks form when the plant materials are rapidly buried under sediment cover and protected from decay by oxygen and organism in an anaerobic condition.

The process by which wood turned into rock is also known as permineralization or petrifaction. The original structure of wood is however normally preserved in such petrified woods and even sometimes the individual structure of cells could be distinguished. Tree rings for example can be observed on many pieces and tissues of the wood could be identified by using microscope. Cast fossil is another fossil group different from petrified wood genetically since it does not contain any part of the original wood material but represents wood in outer morphology. Filling of cavity by various sedimentary materials and subsequent process of cementation transformed the buried plant wood into cast fossil. Fossil parks are declared as protected areas for insitu conservation to combat fossil hunting arising from market value of fossils as semiprecious rocks as well as its collection value among the antique lovers.

With the rise of geotourism, many paleontologically important field sites are conserved in a variety of ways, e.g. from international or national to local and even private levels (Lipps, 2009). A genuine geotourism development strategy for tourism based on the local geology and palaeontology is the key in designing the fossil parks (Pagès, 2009). The fossil forest is considered to be non-renewable natural resource to be preserved not only for admiration of the future generation but also to impart the knowledge on the past climate, past depositional environment of sediments, past geographical conditions, relative age determinations and past ecology (Dietz et al., 1987). From geotourism promotion perspective, the fossil forests have exceptional heritage and scientific values as admired by UNESCO with its recognition under the Global GeoPark Network (Császár et al., 2009). However, the fossils are fragile and very sensitive even to the processes of weathering for which special care is mandatory while promoting geotourism in fossil parks. Geoconservation is a management strategy for the protection of various geoheritage sites with high scientific and tourism values (Gray, 2005). Aim of geoconservation is the dynamic preservation and maintenance of various geoheritage sites (Hose, 2003). With a focus on protection of geosites, geotourism puts emphasis on optimal utilization and diffusion of knowledge about earth heritage resources (Dowling, 2006). The knowledge of geoscience imparting through educative approach of geotourism ultimately benefits the community and the protection of environment at national and local level (Gordon et al., 2012).

The purpose of planning is to design fossil forest as living geomuseum in order to ensure the best possible protection (Pagès, 2009). It is also essential to involve the local communities in geoconservation because authorities are unable to protect the sites directly due to various constraints (Fedonkin et al., 2009). As geotourism yields economic benefit for the community imparting the education and awareness on geosites, it is praised for attaining sustainability perspectives.

\section{OBJECTIVES OF THE STUDY}

In preservation of a geosite, there arises the scope of appreciation of its scientific, educational, aesthetic, cultural and recreational values for the current as well as future generation (Yusry et al., 2018). Under such circumstances, Amkhoi fossil park (23 $37^{\prime}$ 
$\left.25^{\prime \prime} \mathrm{N}, 87^{\circ} 34^{\prime} 56^{\prime \prime} \mathrm{E}\right)$ at Amkhoi village in Illambazar forest of Birbhum district in West Bengal is chosen for the present study with the following objectives:

1. To evaluate the status of Amkhoi fossil park in terms of scientific value, aesthetic value, historical value, education value and recreational value depending on visitors' perception.

2. To assess the aspects of ecological, economic and socio-cultural sustainability in geotourism development with a planning appraisal.

Being considered as geological treasure for experts, researchers, students as well as tourists for the heritage of a million years old buried forest manifested through the presence of both cast fossils and petrified wood fossils, Amkhoi fossil park is regarded as one of the most important destinations to know the geological and biological past of the country (Ghosh, 2019). This paper is an attempt to address the research gap on utilizing the unique characteristics and beauties of the angiosperm wood fossils through sustainable geotourism planning. How the park could contribute to social wellbeing satisfying both the hosts and the guests is the key research question in this context.

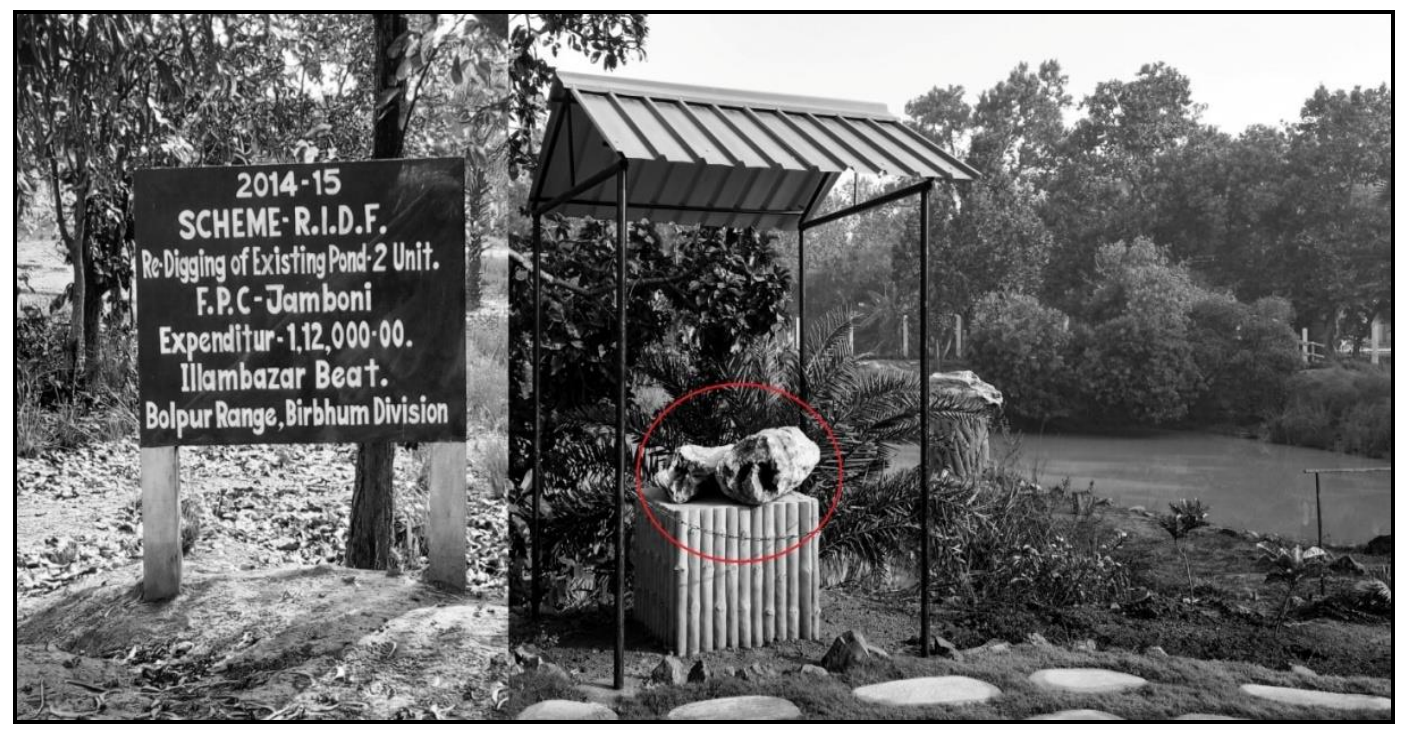

Figure 1. Petrified wood discovered while digging pond in Amkhoi village

\section{BACKGROUND OF THE STUDY}

A number of fossils discovered during various projects of pond digging (Figure 1) at Amkhoi village are identified as angiosperm wood fossils. In Late Miocene period (15-20 million years ago), a vast dry deciduous forest with some evergreen species existed in the uplands of Rajmahal hills and Chotonagpur plateau area. It has been speculated that due to natural calamities, the trees were uprooted in the upper catchment and carried forward to this area in the lower catchment of the drainage basin of present Ajay River by occasional floods before they became petrified.

Petrification generates two major types of wood fossils depending on terrain characteristics: silicified and calcified. In case of Amkhoi village area, a part of such trees which are extinct in this zone but found in other countries like Myanamar and Malaysia even today had been transformed mostly into silicified wood fossils. 
Geologically these fossil woods lie in the Late Tertiary sedimentary sequence called Santiniketan Formation, found in the western part of Bengal which have been exposed in several discrete patches (Ganguli, 1995). From cobble and pebble conglomerate strata as evident in Bonerpukurdanga section of Santiniketan Formation (Figure 2), angiosperm wood fossils have been discovered during digging operations.

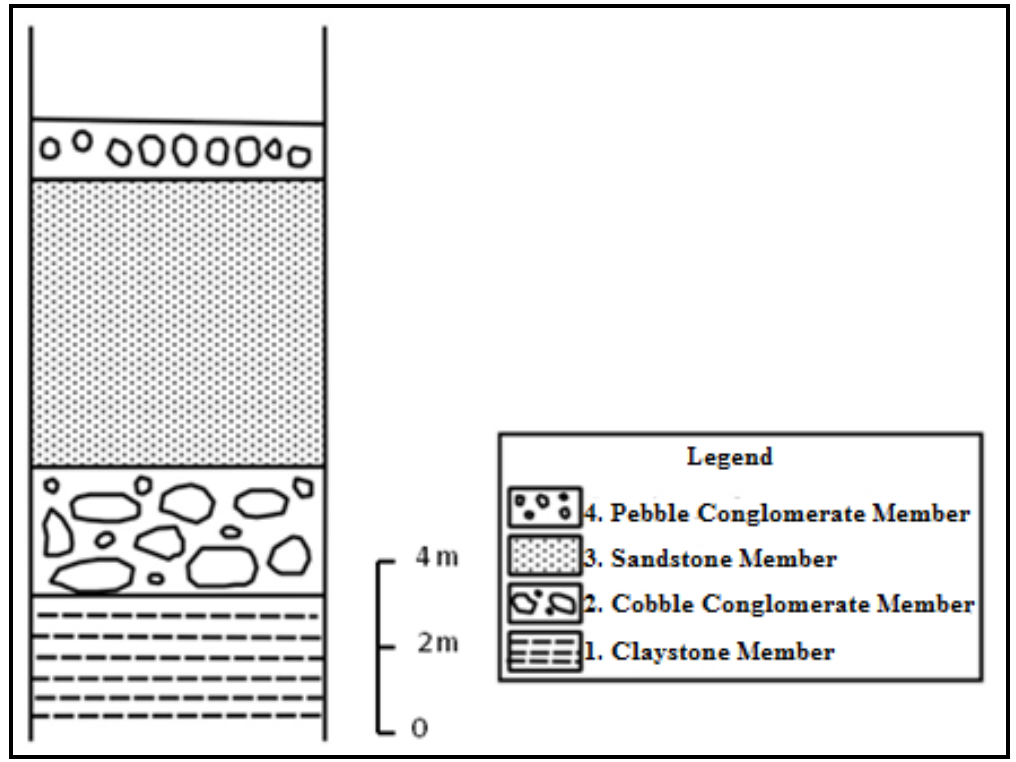

LITHOSTRATIGRAPHIC UNIT OF SANTINIKETAN FORMATION (BONERPUKURDANGA)

Figure 2. Presence of wood fossil in Santiniketan Formation (Source: Ganguli, 1995)

The park has been opened for public on $3^{\text {rd }}$ January in the year 2018 as the first fossil park of West Bengal for geotourism (Figure 3).

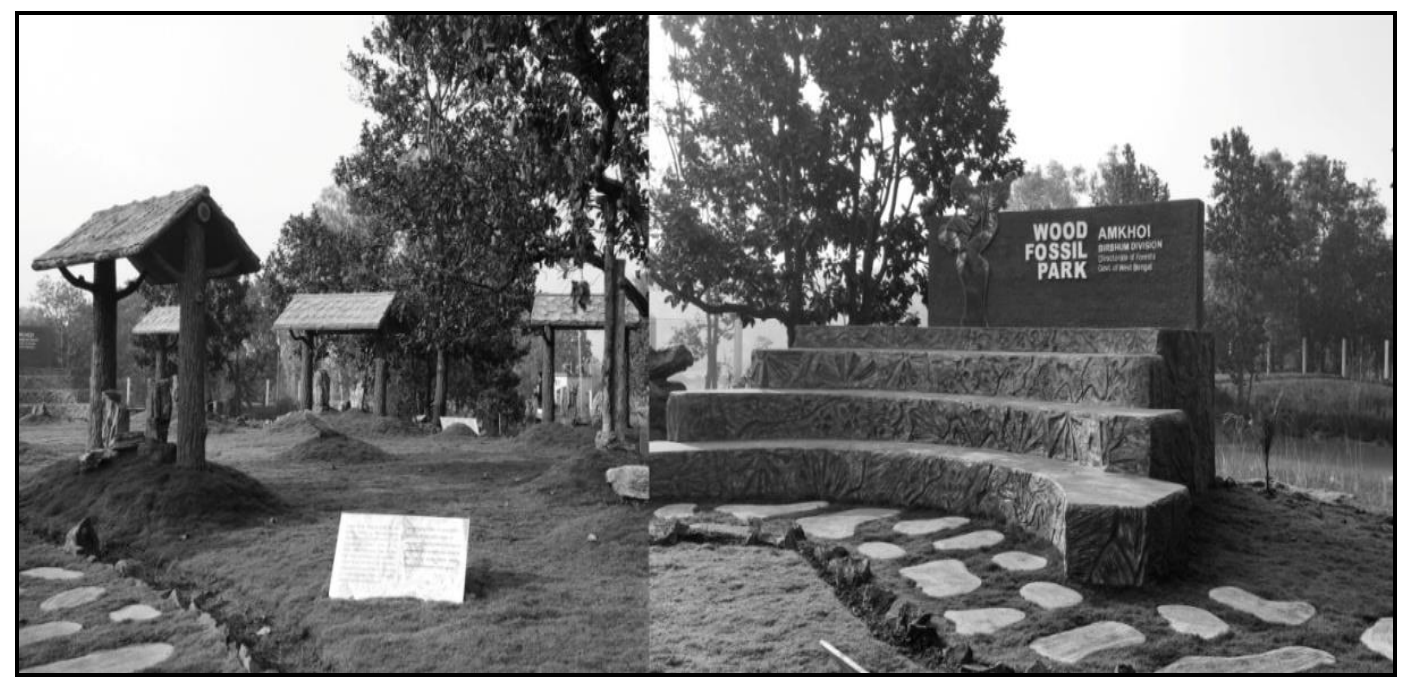

Figure 3. Amkhoi fossil park and its ambience 


\section{MATERIALS AND METHODS}

Ethnographic methods have been applied to explore the perception of visitors while enjoying the flavour of geotourism experience during their visit at Amkhoi fossil park. Interviews have been conducted to investigate the behavioural intention of the tourists towards the following values based on a five point Likert Scale:

- $\quad$ Scientific value

- $\quad$ Aesthetic value

- $\quad$ Historical value

- $\quad$ Educational value

- Recreational value

While the tourists have entered the compound of the fossil park and photographing the objects according to their choice, they have been asked the reason of making particular photos with request to provide quantitative values in Likert Scale on the aspects already mentioned. After obtaining the data on factors motivating their visit, questionnaires have been distributed following stratified purposeful sampling of the visitors to derive their perception on the various aspects of geoconservation.

A special emphasis was also given to identify the problems of geotourism in Amkhoi fossil park. The tourists have been categorically asked to express their observations on the sustainability status of fossil park. A number of variables have been derived further for interviewing the host population on the aspects of ecological, economic and socio-cultural sustainability concerning the fossil park management. Taking into account a number of sustainability concerns put forwarded for different level of agreements (Table 1), a Principal Component Analysis (PCA) is attempted.

A planning map is generated for improvement of the fossil park and its ambience through instrumental survey incorporating both the demand of guests and expectations of the host population as derived from ethnographic surveys.

\section{RESULTS AND DISCUSSIONS}

Raising geoconservational awareness is precondition for the sustainable management of any geotourism landscape (Chakrabarty et al., 2019).

Tourists motivation of Amkhoi Wood Fossil Park

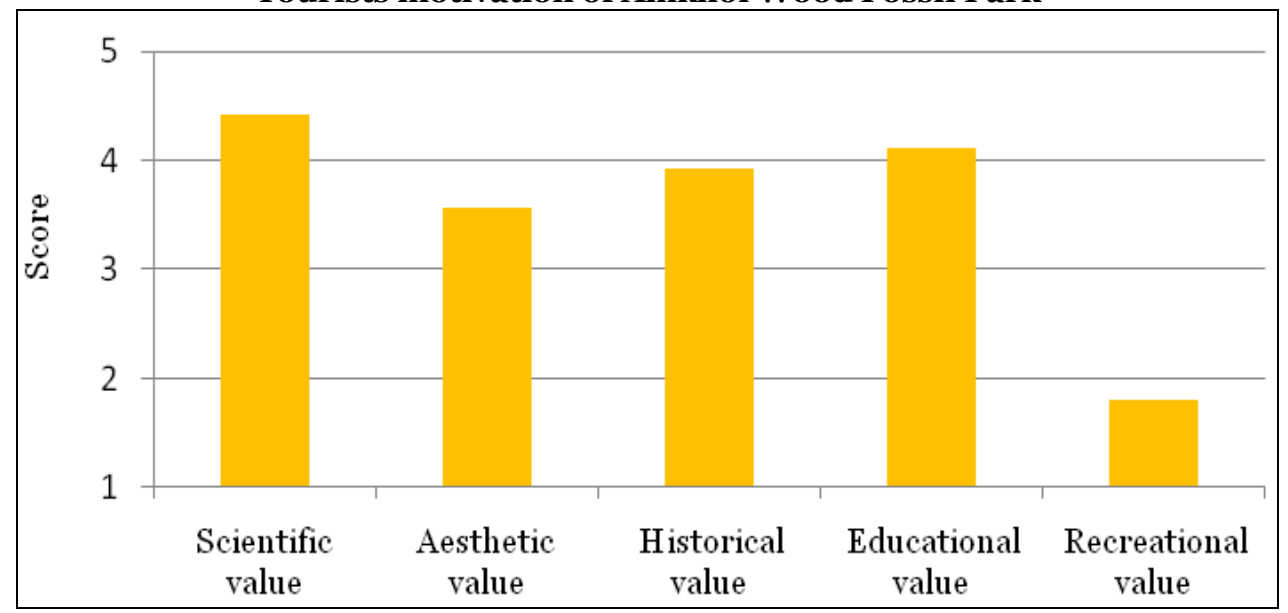

Figure 4. Visitors' response in Likert Scale on different value aspects influencing travel motivation (Source: Field survey, 2018-19) 
Geotourism in Amkhoi is now in juvenile stage and the park is visited by 300-350 persons/week on an average. In order to find out the motivation of their visit along with awareness level, their responses have been recorded in five point Likert Scale. Figure 4 provides a comparison between such values obtained from ethnographic surveys.

From the analysis of the visitors' response, it is revealed that most important factor which motivated them is the scientific value of the Fossil Park. Scientific value arises from the interests on how such fossils were formed, what process shaped these fossils etc. When attraction of fossils have been given special geological and paleontological significance in their responses, there arises the educational value of geotourism. Further understanding of fossils as the evidence of climate change, linkages between the earlier organisms and the present day organisms generate the historical value of the fossils. As presently it is more a place for excursion of educational institutions and dedicated geotourists rather that recreational visitors, less score on recreational value than aesthesic value is obtained during survey. A number of issues related to the ecological, economic and socio-cultural sustainability concerning fossil park have been discussed with the host community during the interaction with them.

They have been agreed on varying percentages with the issues raised (Table 1), which is further analyzed with the application of reliability analysis followed by a PCA (Principal Component Analysis) ultimately deriving the grouping of variables into factor 1 (Socio-economic aspects) and factor 2 (Ecological and environmental aspects) for further analysis of their relative importance (Table 2).

Table 1. Agreement status of respondents from host population on sustainability concerns (Data source: Field survey, 2018-19)

\begin{tabular}{|c|c|c|c|c|c|}
\hline \multirow{2}{*}{$\begin{array}{c}\text { Sustainability concerns } \\
\text { SD=Strongly Disagree, } D=\text { Disagree, } \\
\text { N= Neutral, } \mathbf{A}=\text { Agree }, \mathbf{S A}=\text { Strongly Agree }\end{array}$} & \multicolumn{5}{|c|}{ Rate of agreement (\%) } \\
\hline & SD & $\mathbf{D}$ & $\mathbf{N}$ & $\mathbf{A}$ & SA \\
\hline $\begin{array}{l}\text { 1. Adequate preservation of petrified woods as common } \\
\text { property resource }\end{array}$ & o & 5.26 & 15.79 & 29.83 & 49.12 \\
\hline $\begin{array}{l}\text { 2. Provision of infrastructural expansion with GeoPark } \\
\text { development }\end{array}$ & 26.32 & $33 \cdot 33$ & 29.82 & 7.02 & 3.51 \\
\hline 3. Adoptability of sound waste management plan & 45.61 & 42.11 & 12.28 & $\mathrm{o}$ & o \\
\hline $\begin{array}{l}\text { 4. General cleanliness being improved after the } \\
\text { development of GeoPark }\end{array}$ & 7.02 & 8.77 & 19.30 & 42.10 & 22.81 \\
\hline 5. Creation of new job opportunities in and around GeoPark & 26.32 & & & & 3.51 \\
\hline $\begin{array}{l}\text { 6. Increase in the number of commercial establishment } \\
\text { after the development of GeoPark }\end{array}$ & $47 \cdot 37$ & 38.60 & 10.52 & 3.51 & o \\
\hline $\begin{array}{l}\text { 7. Awareness on nature and cultural values of fossil } \\
\text { increased after GeoPark development }\end{array}$ & o & 7.02 & 17.54 & $47 \cdot 37$ & 28.07 \\
\hline $\begin{array}{l}\text { 8. Increase in the number of financial institution } \\
\text { providing loan for business after GeoPark development }\end{array}$ & 40.35 & 49.12 & 8.77 & 1.76 & o \\
\hline $\begin{array}{l}\text { 9. Landuse change for geotourism promotion reaping } \\
\text { benefits for the host population }\end{array}$ & 22.81 & 35.09 & 26.31 & 12.28 & 3.51 \\
\hline $\begin{array}{l}\text { 10. Economic condition of the local people being } \\
\text { improved after the development of GeoPark }\end{array}$ & 31.58 & 43.86 & 15.79 & 7.02 & 1.75 \\
\hline
\end{tabular}

From table 2, it appears that ecological and environmental aspects seem to outweigh the socio-economic aspects concerning the geopark management. The 
vulnerability of fossils is one of the key issues to be dealt with while studying the sustainability aspects. Though it is considered that geotourism can be a powerful tool for sustainable development but if it is not managed responsibly, it can constitute a direct threat to geoheritage resources (Burek \& Posser, 2008; Newsome et al., 2012). The following facts are outcomes of the persistent observation for vulnerability assessment of the Amkhoi fossil park:

1. The local community is almost detached from park protection and management practices as the park is separated by an enclosure for geoconservation purpose by forest department of the government. There arises frustration in the community since among the 28 families in the village, only 17 members have been presently employed with a very low wage rate and their services are not declared permanent also.

2. The carrying capacity problem due to influx of large number of visitors at a time may lead to degradation of the geopark in near future. Fossils are also found scattered outside the park enclosure almost unprotected.

3. In weekends, the recreationists visit the fossil park and arrange picnic outside its present encloser polluting the environment contributing both bio-degradable and nondegradable wastes, particularly the plastics.

Table 2. Status of variables under study

\begin{tabular}{|c|c|c|c|c|}
\hline \multicolumn{3}{|c|}{ Sustainability concerns } & Mean & $\begin{array}{l}\text { Standard } \\
\text { Deviation }\end{array}$ \\
\hline \multirow{6}{*}{$\begin{array}{l}\text { Factor 1: Socio- } \\
\text { economic } \\
\text { aspects }\end{array}$} & & $\begin{array}{l}\text { Increase in the number of commercial } \\
\text { establishment after the development of } \\
\text { GeoPark }\end{array}$ & 1.70 & 0.79 \\
\hline & & $\begin{array}{l}\text { Increase in the number of financial } \\
\text { institution providing loan for business } \\
\text { after GeoPark development }\end{array}$ & 1.72 & 0.69 \\
\hline & V10 & $\begin{array}{l}\text { Economic condition of the local people being } \\
\text { improved after the development of GeoPark }\end{array}$ & 2.04 & 0.95 \\
\hline & & $\begin{array}{l}\text { Infrastructural expansion with GeoPark } \\
\text { development }\end{array}$ & 2.28 & 1.04 \\
\hline & & $\begin{array}{l}\text { Creation of new job opportunities in and } \\
\text { around GeoPark }\end{array}$ & 2.23 & 1.04 \\
\hline & & $\begin{array}{l}\text { Landuse change for geotourism promotion } \\
\text { reaping benefits for the host population }\end{array}$ & 2.39 & 1.07 \\
\hline \multirow{4}{*}{$\begin{array}{l}\text { Factor 2: } \\
\text { Ecological and } \\
\text { environmental } \\
\quad \text { aspects }\end{array}$} & & $\begin{array}{l}\text { General cleanliness being improved after the } \\
\text { development of GeoPark }\end{array}$ & 3.65 & 1.13 \\
\hline & & $\begin{array}{l}\text { Raising awareness on nature and cultural } \\
\text { values after GeoPark development }\end{array}$ & 3.96 & 0.86 \\
\hline & & $\begin{array}{l}\text { Better preservation of petrified woods as } \\
\text { common property resource }\end{array}$ & 4.23 & 0.90 \\
\hline & & $\begin{array}{l}\text { Sound waste management plan undertaken } \\
\text { with expansion of geotourism activities }\end{array}$ & 1.67 & 1.29 \\
\hline
\end{tabular}

From ideological perspective, geotourism assists sustainable development of geoparks and local communities (Hose, 2011). A geological itinerary is advocated for the purpose of geoconservation by raising the awareness of geological heritage within the local population (Rapidah et al., 2018). Any sound geotourism management plan should 
aim at limited provision of the infrastructure and services/facilities involving local community in order to protect the geoheritages of the endangered fossils.

The involvement of local community in conservation and valuation of geological heritage is recognized worldwide because their perceptions may help to maintain and protect local geosites and raise public awareness of environmental aspects (Avelar et al., 2015). Involvement of local communities is not only positive for the local economy but also there arises the scope for utilization of indigenous knowledge (Farsani, 2009). Their indigenous knowledge and traditional lifestyle may offer aditional attraction for geotourists who are primarily attracted for the discovery of a million years old buried forest found at different layers in the region.

Establishment of a geomuseum may be a watershed development in attracting visitors by adding more scientific value in travel motivation. The geomuseum with multimedia interpretation techniques related to fossil and geology of the study area may address the following queries:

1) What is fossil and how it was created?

2) What could be known from these fossils?

3 ) What is the past geological history of the area?

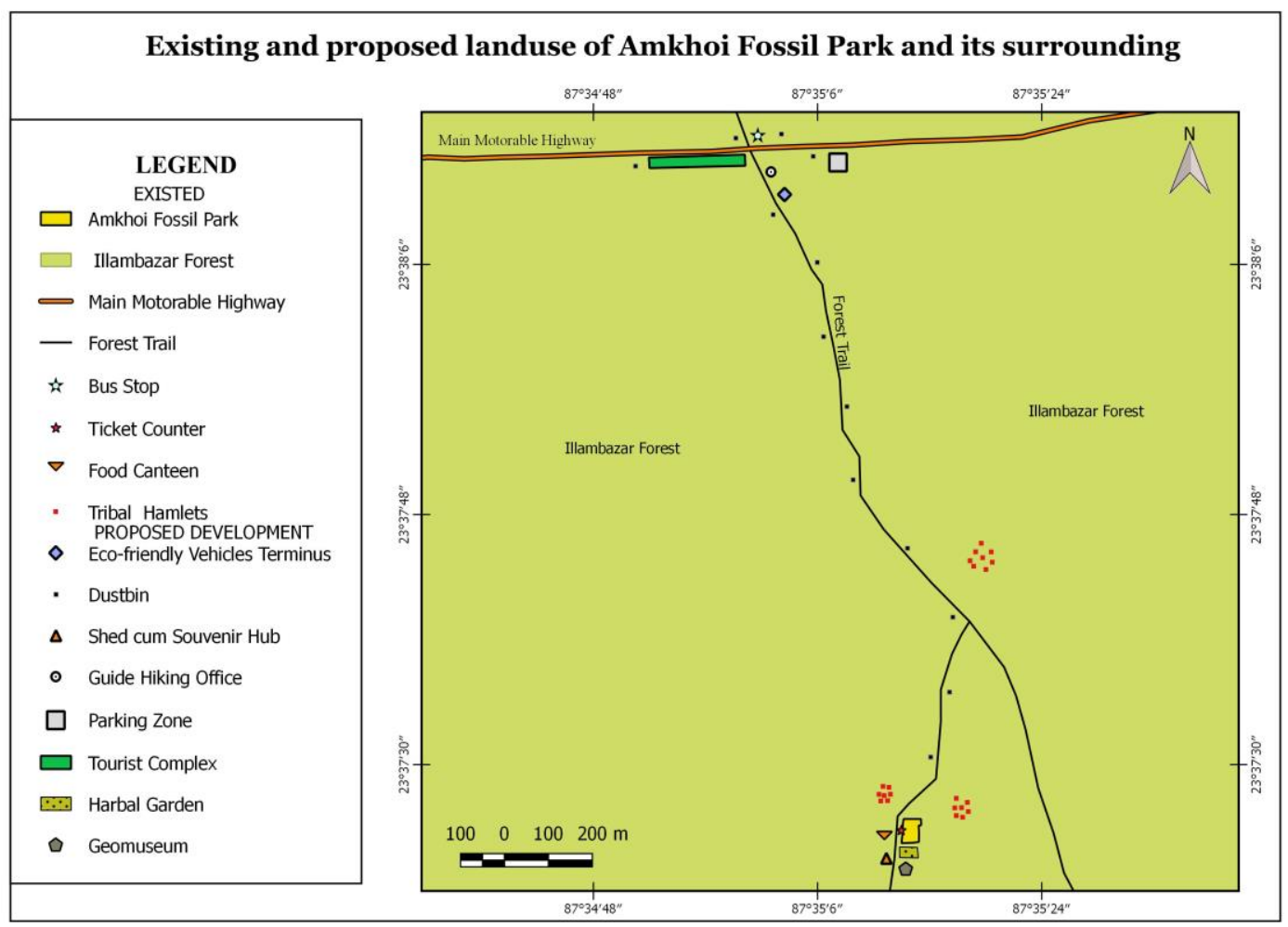

Figure 5. Planning map for Amkhoi Fossil Park (Source: Prepared by authors, 2019)

The geoconservation training is essential to gain knowledge about geology and paleontology in order to be absorbed in geotourism industry as guide, who can interpret fossils and their geological characteristics evaluating the educational, historical and 
scientifical values satisfying the travel motivation. Interpretation is an essential provision for public understanding while experiencing about places which are visited (Wang et al., 2014). Effective interpretation system is required to promote sustainable tourism and recreation (Moscardo, 1998). Interpretation of the features should be well understood not only by the academic community but also by the common tourists for the interset of mass education. So the site based interpretation should be very transparent, so that such can diffuse the scientific knowledge making people aware about the geosites along with the increase of the interests in the field of geoconservation (Hose, 2012). Visitors may seek various information and knowledge about the area, the history of the fossils, scientific value of fossils from them. There may be homestay facilities for the visitors, who want to stay a night to enjoy the calmness of the forest after being enlighted on fossils. When local people get some benefits from the park, they feel proud to protect and manage the vulnerable fossils as geotourism resources.

In order to advance geoconservation and geotourism hand in hand, it is essential to create useful maps (Serrano \& Gonzaloz Trueba, 2011). The planning map (Figure 5) is cognitive one arising from instrumental survey for existing land use combined with ethnographic survey outcomes. A trekking through the forest trail is suggested as mandatory for everyone to reach the destination in order to safeguard the environment from the future carrying capacity problems. The park is located about two kilometers away from the main road. A tourist complex with modern facilities and amenities at the junction of main road and forest trail is required. Willing visitors have to leave their cars in the parking area that has been specified at or near the tourist complex and opt to walk to reach the proposed park museum. Eco-friendly vehicles may also be provided for the older and incompetent visitors to transport them upto the park gate.

To avoid pollution within the park boundary and surrounding forest area, there is scope of the imposition of Polluter Pay Principles (PPP). Along the trekking trail, biodegradable and non biodegradable dustbins may be made available at an interval of about 100 meters. These dustbins should be cleaned regularly by the local community being involved in park management.

With an audio-visual fossil interpretation centre as geo-museum and a herbal garden for the rest and relaxation of visitors outside the protected area enclosure, Amkhoi fossil park may perform better from geotourism as well as geoconservation perspectives.

\section{CONCLUSION}

Lack of effective conservation management plan, the uncoordinated development, and the unsubstantial interpretation system are among the main problems of the protection of geoheritages (Wang et al., 2014). It affects geotourism directly since with the degradation of georesources, the geotourism destinations may not be capable to attract tourists (Schlüter et al., 2018). The adaptation of the strategy of geoconservation is considered as a positive element for local development and management plan implementation (Prosser, 2011). For conserving the geoheritage like fossils, it is necessary to mobilize local awareness. This awareness could be generated through increasing local sense and appreciation of local pride and respect towards geoheritage and also for mutual economic interests but it is not required to follow strict scientific criteria and divisions (Erikstad, 2012). This is very much applicable for Amkhoi wood fossil park, which is still in infancy stage. Before understanding the value of fossils, the local community used them as ordinary rocks for domestic use, even for 
washing their cloths. No objection was usually made by them previously when outsiders came and collected the petrified woods from their area.

The situation is however gradually changing and it is very important from the standpoint of geoconservation because the presently protected site is only the core area of fossil discovery while its periphery extending about 10 hectares of area is endowed with such fossils. Effective community involvement in managing the fossil park is therefore vital for its sustainable utilization for geotourism purpose.

Sustainable development of geotourism centring Amkhoi fossil park may contribute to the wellbeing of the hosts and value orientation of the guests in term of scientific, aesthetic, historical, educational and recreational standpoints.

\section{Acknowlegment}

We do hereby acknowledge Dr. Urmila Ganguli, an eminent geologist devoted to the well-being of the Amkhoi Fossil Park since the date of discovery of fossils in this area.

\section{REFERENCES}

Avelar, S., Mansur, K., L., Anjos, S., C., \& Vasconcelos, G., F. (2015). Community Perceptions for Geoconservation of a Coastal Area in Rio de Janeiro, Brazil. Geoheritage, vol. 7, no. 3, p. 275-283, Springer.

Badam, G., L. (1979). Pleistocene Fauna of India. Deccan College Post-graduate and Research Institute, Pune.

Badam, G., L. (1988). Quaternary Faunal Succession of India. Geological Survey of India, Special Publication 2 (11), p. 277-304.

Badam, G., L., \& Sathe, V. (1995). Palaeontological Research in India: Retrospect and Prospect. In: Wadia, S., Korisettar, R., Kale, V., S. (Eds.), Quaternary Environments and Geoarchaeology of India, Essays in Honour of Professor S. N. Rajaguru. Memoirs of the Geological Society of India 32, Bangalore, p. 473-495.

Boonchai, N., Grote, P., J., \& Jintasakul, P. (2009). Paleontological parks and museums and prominent fossil sites in Thailand and their importance in the conservation of fossils. Notebooks on Geology - Book 2009/o3 (CG2009_Bo3), Chapter 7, p. 75-95.

Burek, C., V., \& Prosser, C., D. (2008). The history of geoconservation: an introduction. Geological Society, London, Special Publications 300, p. 1-5.

Chakrabarty, P., \& Mandal, R. (2019). Geoarchaeosites for geotourism: A spatial analysis for Rarh Bengal in India. GeoJournal of Tourism and Geosites, vol. 25, no. 2, p.543-554.

Chakrabarty, P., Pan, S., \& Mandal, R. (2019). Promoting wildlife tourism on geotourism landscape: A study in Manas and Kaziranga National Parks of Assam, India. GeoJournal of Tourism and Geosites, vol. 24, no. 1, p.189-200.

Császár, G., Kázmér, M., Erdei, B., \& Magyar, I. (2009). A possible Late Miocene fossil forest PaleoPark in Hungary. Notebooks on Geology - Book 2009/03 (CG2009_Bo3), Chapter 11, p. 130.

Dietz, R., S., Pewl, T., L., \& Woodhoush, M. (1987). Petrified Wood (Araucarioxylon Arizonicum): Proposed as Arizona's State Fossil. Journal of the Arizona-Nevada Academy of Science, vol. 22, issue 2, p. 110.

Dowling, R., \& Newsome, D. (2006). Geotourism. Oxford: Elsevier Ltd.

Erikstad, L. (2012). Geoheritage and geodiversity management - the questions for tomorrow. Proceedings of the Geologists' Association, vol. 124, p. 713-719, Elsevier Ltd.

Farsani, N., T., Coelho, C., \& Costa, C. (2009). Geotourism as an opportunity for local communities' participation in geoparks. In: de Carvalho CN, Rodrigues J (eds), New challenges with geotourism, Proceedings of the VIII European geoparks conference Idanha-a-Nova, Portugal.

Fedonkin, M., A., Ivantsov, A., Y., Leonov, M., V., Lipps, J., H., Serezhnikova, E., A., Malyutin, E., I., \& Khan, Y., V. (2009). Paleo-piracy endangers Vendian (Ediacaran) fossils in the White Sea - Arkhangelsk region of Russia. Notebooks on Geology - Book 2009/o3 (CG2009_Bo3), Chapter 9, p. 108.

Ganguli, U. (1995). A new lithostratigraphic unit at the Western fringe of West Bengal, India. India Journal of Geology, vol. 67, no. 4, p. 282-288.

Ghosh, D. (2019). Amkhoi - youngest wood fossil park of India. Science Reporter, NISCAIR-CSIR, India, vol. 56 , no. 8, P. 45-48.

Gordon, J., E., Barron, H., F., \& Miller, A., D. (2012). New directions in geoconservation: Scotland's Geodiversity Charter. European Geologist, vol. 34, p. 51. 
Gray, M. (2005). Geodiversity and geoconservation: what, why, and how? In: Santucci, V.L. (Ed.), Papers Presented at the the George Wright Forum, p. 4-12.

Hose, T., A. (2003). Geotourism in England: a Two-region Case Study Analysis. Ph. D. University of Birmingham, Birmingham.

Hose, T., A. (2011). The English origins of geotourism (as a vehicle for geoconservation) and their relevance to current studies. Acta Geographica Slovenica, vol. 51 (3), p. 343-359.

Hose, T., A. (2012). 3G's for Modern Geotourism. Geoheritage, vol. 4 (1-2), p. 7-24.

Lipps, J., H. (2009). PaleoParks: Our paleontological heritage protected and conserved in the field worldwide. Notebooks on Geology - Book 2009/03 (CG2009_Bo3), Chapter 1, p. 2.

Mishra, V., P. (2008). Geoparks of India: Museum of natural sculptures, e-Journal Earth Science, India, Popular Issue.

Moscardo, G. (1998). Interpretation and sustainable tourism: functions, examples and principles, The Journal of Tourism Studies, vol. 9 (1), p. 2-12.

Newsome, D., Dowling, R., \& Leung, Y-F. (2012). The nature and management of geotourism: a case study of two established iconic geotourism destinations. Tourism management perspectives, vol. 2-3, p. 1927, Elsevier Ltd.

Pagès, J., S. (2009). The GeoPark of Haute-Provence, France - Geology and palaeontology protected for sustainable development. Notebooks on Geology - Book 2009/o3 (CG2009_Bo3), Chapter 3, p.29-34.

Prosser, C., D. (2011). Principles and Practice of Geoconservation: Lessons and case law arising from a legal challenge to site-based conservation on an eroding coast in Eastern England, UK. Geoheritage, vol. 3, Issue 4, p. 277-287, Springer.

Rapidah, M., S., Mohamed, K., R., Ali, C., A., Leman, M., S., \& Saidin, M. (2018). A geotouristic itinerary: a proposal for geotourism and archaeotourism development of Lenggong valley, Perak, Malaysia. GeoJournal of Tourism and Geosites, vol. 22, no. 2, p. 597-624.

Schlüter, T., \& Schumann, A. (2018). Geosites as a potential for the development of tourism - overview of relevant sites in Eswatini (formerly Swaziland). GeoJournal of Tourism and Geosites, vol. 22, no. 2, p.535-547.

Serrano, E., \& González Trueba, J., J. (2011), Environmental Education and Landscape Leisure. Geotourist Map and Geomorphosites in the Picos De Eurora National Park, GeoJournal of Tourism and Geosites, Year IV, no. 2, vol. 8, p-307.

Wang, L., Tian, M., Wen, X., Zhao, L., Song, J., Sun, M., Wang, H., Lan, Y. \& Sun, M. (2014).Geoconservation and geotourism in Arxan-Chaihe Volcano Area, Inner Mongolia, China. Quaternary International 349, p. 384-391, Elsevier Ltd. and INQUA.

Yusry, M., Simon, N., \& Unjah, T. (2018). Geodiversity and geoheritage assessment in Hulu Langat District, Selangor, Malaysia. GeoJournal of Tourism and Geosites, vol. 23, no. 3, p. 861-872.

Submitted:

26.06.2019
Revised:

18.12.2019
Accepted and published online

20.12.2019 